\title{
CHANGING ROLE OF PENSION FUNDS AND INSURANCE COMPANIES AS SOURCES OF HOUSEHOLD WELL-BEING IN THE LONG TERM: THE EXAMPLE OF THE COUNTRIES OF THE FORMER SOVIET UNION
}

\author{
Andrei A. BRYLEV*, Anastasia N. MITROFANOVA, Victoria A. KHOTEEVA \\ Risk Management and Insurance Department, Saint Petersburg State University, \\ 7-9 Universitetskaya nab., 199034 Saint Petersburg, Russian Federation
}

Received 28 February 2021; accepted 01 April 2021

\begin{abstract}
Purpose - the main objective of this study is to assess the impact of investments in pension and insurance schemes on household well-being, based on an analysis of data from the countries of the former Soviet Union in the long term.

Research methodology - using empirical analysis, the assets and liabilities of households are examined, divided into the main financial market instruments in the selected countries.

Findings - the calculations confirmed the relationship between total household assets and assets held in life insurance reserves and pension schemes.

Research limitations - the choice of the countries is determined by the similarity of the economies and the political and social systems. Also, the choice of countries is due to the lack of data, so the number of countries studied was reduced to 6 .

Practical implications - the results of this study will be useful for national governments and major institutional investors.

Originality/Value - although similar studies were conducted on the basis of data from OECD countries, a comparable cross-country analysis was not conducted on the data of the countries of the former Soviet Union. Further, on the basis of the obtained data, it is planned to conduct a correlation and regression analysis to identify the statistical relationship.
\end{abstract}

Keywords: pension fund, insurance company, household, wellbeing.

JEL Classification: G52, O57.

Conference topic: Contemporary Financial Management.

\section{Introduction}

The insurance industry and the voluntary pension insurance industry are critical components of the economy because of the amount of premiums they collect, the scale of their investments, and, more importantly, the significant social and economic role they play in covering personal and business risks.

In recent years, there have been intensive pension reform efforts in countries around the world, often linked to the increased use of private-sector funded pension schemes. These savings mechanisms are likely to play an increasingly important role in providing retirement income in many countries, and private pension assets will play an increasingly important role in financial markets, especially as a source of long-term savings.

The increase in total premiums in the life insurance sector in some countries may be the result of increased consumer awareness and interest in life insurance products.

In Lithuania, the number of new insurance contracts peaked in June and July 2019, following a pension reform that gives employees until the end of June 2019 the opportunity to choose whether to participate in a workplace pension plan or not. Lithuanian policyholders purchase insurance contracts as a supplement (in some cases) or as an alternative (in other cases) to participation in a workplace pension plan.

*E-mail: bryliov.andrey@yandex.ru

(C) 2021 Authors. Published by Vilnius Gediminas Technical University. This is an open-access article distributed under the terms of the Creative Commons Attribution (http://creativecommons.org/licenses/by/4.0/) License, which permits unrestricted use, distribution, and reproduction in any medium, provided the original author and source are credited. 
Since the creation of the mandatory funded component, the pension system of Russia, as well as other countries of the former Soviet Union (FSU), has been constantly reformed for several decades. However, the results of the reforms and their practical implementation continue to cause controversy to this day.

The constant reform of the pension system has created a weak confidence in the pension system on the part of the population.

In this regard, the appeal to the foreign experience of pension provision in other countries seems to be the most reasonable action.

The multi-level pension system in Russia has a number of unresolved problems. The greatest controversy recently accompanied the issues of raising the retirement age. Pension institutions in the CIS countries do not correspond to the new social order, changed social and labor relations, and the current demographic situation. Thus, the income of the majority of pensioners is close to the subsistence minimum, and in some countries of the FSU is even lower.

A large proportion of workers in the total economically active population face high risks of non-participation or partial participation in pension insurance, which in turn cause the risks of poor old age. This leads to a weakening of the financial support capabilities of the pension system, instability of its functioning, and the threat of full fulfillment of state pension obligations to the population.

A low level of financial literacy negatively affects the personal well-being and financial potential of households, worsens the resource base of financial organizations, hinders the development of the financial market, slows down investment processes in the economy and leads to a deterioration in the socio-economic situation of the country

Thus, in contrast to the advanced economies of the European Union, the link between pension savings and household income in the FSU countries is not so obvious, since the pension systems in the FSU countries are in a period of active reform, which changes the pension systems of the countries. Therefore, the authors put forward the goal to check whether this connection is present and how strong it is.

\section{Literature review}

Domestic and foreign researchers have different approaches to assessing household assets. Focusing on household financial assets, (Bernard \& Berthet, 2016; Sim \& Lee, 2020) base their research on the expansion of life insurance in the portfolio of French households, describing its nature and which groups of depositors supported it (Kunovac, 2020). analyzes the main components and distribution of assets in Croatia, taking into account the various socio-demographic characteristics of households. Some authors reflect heterogeneity in socio-demographic and measurement data (Bover et al., 2016; Tomaszewicz, 2014). In the same way, (Pastoráková et al., 2017), identifies the factors that determine the proactive approach of individuals to private life according to the "Pension-Savings" model, while our study adds an assessment of the total and financial assets of households, as well as household assets in the life insurance reserves and pension schemes of the FSU countries.

Van Santen (2019) estimates the savings equation using a simple life-cycle model with income uncertainty, using data from a survey of Dutch households, with subjective expectations about pension payments and uncertainty (Gomes et al., 2020) provide an overview of the rapidly expanding literature on household finance (with some important exceptions) and suggest directions for future research, our analysis will complement the existing list on a given topic. (Jang, 2019) considers the transition from public to private pension schemes, and it is expected that their increase will lead to an increase in income inequality. Therefore, using data from the OECD, SOCX, this study examined how the impact of private pensions on income inequality can be altered by the institutional design of public pension systems.

Brown et al. (2015) contribute to the empirical literature on household finance by introducing the Bayesian multivariate two-part model, while our estimate in this analysis is based on multiple regression based on panel data. The researchers take into account the potential interdependence between asset ownership and liabilities at the household level, which involves a two-part process to account for differences in the impact of asset ownership or liabilities on the respective amounts held. state pension systems.

Some researchers (Kukk, 2017; Rosa, 2016; Levine, 2013) consider household wealth from the perspective of their liabilities and believe that higher household liabilities are associated with a lower level of ownership of financial assets, while our study analyzes the level of relationship between household assets in the FSU countries.

Population ageing and pension reforms significantly affect household well-being indicators such as consumer spending, income, assets, and poverty (Unnikrishnan \& Imai, 2020). Another authors (Obben \& Waayer, 2011) aim to redefine the relationship between social security and the household. The authors findings show that concerns about accumulating assets to match life expectancy at the current retirement age overwhelm the view that retirement benefits are an adequate replacement for household assets.

Domestic researchers (Belozyorov \& Pisarenko, 2015; Pisarenko \& Kuznetsova, 2019; Kuznetsova \& Pisarenko, 2016) also believe that the existing solidarity system in the studied countries, together with pension reforms, is not able to provide the necessary level of household welfare. To reduce the pressure on the pension system, it is necessary to redistribute financial flows by expanding the sources of financing and transferring the risk of old age to the individual level, thus, the role of such institutional investors as pension funds and insurance companies is significantly increased. 
There are researchers who argue that (Morozko \& Didenko, 2018), who believe that the main type of savings of Russian households is deposits in national and foreign currencies, rather than pension and insurance schemes, focus on an empirical analysis of the relationship between gross savings and bank variables, such as demand deposits, interest spread, and the ratio of bank capital to assets.

However, researchers from Russian regions (Boldyreva \& Reshetnikova, 2020; Chernova et al., 2010) in their study demonstrate that bank deposits can protect capital from depreciation, but do not allow the accumulation and multiplication of funds, especially during crisis periods. In contrast, voluntary retirement portfolios (conservative, balanced, and aggressive) show cash gains when managing the investments of a portfolio containing stocks. Pension asset managers improve the effectiveness of their investment policies in accordance with the rules for investing pension funds.

In their paper, (Liu et al., 2014) build a model for managing household assets and liabilities using the theory of multi-purpose optimization. The authors also use statistical and random programming methods to work with the wandering parameter and want to transfer the model to the stated decision problem and determine the optimal decision strategy for the household.

Thus, the topic is well-developed and studies of the level of household wealth and the assets that affect it are quite popular. However, the impact of insurance companies and pension funds on household well-being has not been sufficiently studied in the context of the countries of the former Soviet Union, which is the novelty of this study.

\section{Research data and method used}

The combination of low private savings rates and the projected increase in the fiscal burden of financing the state pension system for an aging population poses a serious problem. That is why, at present, households are increasingly resorting to the search for alternative forms of savings and savings of money to form well-being in the long term, thereby explaining the relevance of this study.

Our estimates are based on total and financial household assets, as well as household assets in life insurance reserves and pension schemes. This diversification of sources of income in old age shifts the responsibility for the level of pension income to the people themselves and at the same time opens up the question of their readiness for such financial decisions. Insufficient savings can have a huge impact on their future lives and determine their standard of living during retirement. The novelty of the study lies in the absence of such an analysis on the example of the countries of the former Soviet Union.

The research was carried out on the basis of such scientific methods as: empirical analysis, analysis and synthesis, statistical analysis (correlation and regression analysis). A similar model (threshold autoregressive methodology) is used in their work by (Manou et al., 2020). A multiple regression was constructed based on the panel data. The latter consist of observations of the same economic units or objects (individuals, households, firms, regions, countries, etc.), which are carried out in successive periods of time. Thus, this data combines both spatial type data and time series type data: at each moment of time, there is spatial type data for economic units, and for each object, the corresponding data forms one or more time series. The statistical significance of the regression equations was checked using the coefficient of determination, the Student's test, and the Fisher test, and the remainder was checked for autocorrelation using the Darbin-Watson test.

The authors put forward a hypothesis about the impact of household assets invested in voluntary pension schemes and life insurance on the overall level of household well-being in the long term.

The data for the study were obtained from open sources on the Internet: the official websites of national banks and statistical agencies of the countries under study, as well as international organizations (The World Bank, n.d; Organisation for Economic Co-operation and Development [OECD], 2019; International Labour Organization [ILO], 2017).

The following countries were selected for the study: the Russian Federation, Latvia, Lithuania, Estonia, Belarus and Kazakhstan. The choice of the countries is determined by the similarity of the economies and the political and social systems. Latvia, Lithuania, and Estonia are the only FSU countries that have joined the European Union, while Belarus, Kazakhstan, and Russia are major breakout economies compared to other FSU countries. Also, the choice of countries is due to the lack of data, so the number of countries studied was reduced to 6 .

\section{Results and discussion}

Household finance as one of the elements of a country's financial system may be of considerable interest to researchers. Households participate in almost all areas of financial relations through the formation of the income base, spending in various areas, and investment activity.

Figure 1 shows the dynamics of household financial assets based on OECD data. Despite the economic turbulence, there has been a steady increase in household financial assets in the countries studied over the period 2000-2019.

With global economic growth slowing and political pressure increasing, the role of institutional investors in the domestic financial market, such as pension funds and insurance companies, is rapidly increasing, as shown in Figures 2 and 3. 
A. A. Brylev, A. N. Mitrofanova, V. A. Khoteeva. 2021. Changing role of pension funds and insurance companies as sources of household well-being in the long term: the example of the countries of the former Soviet Union

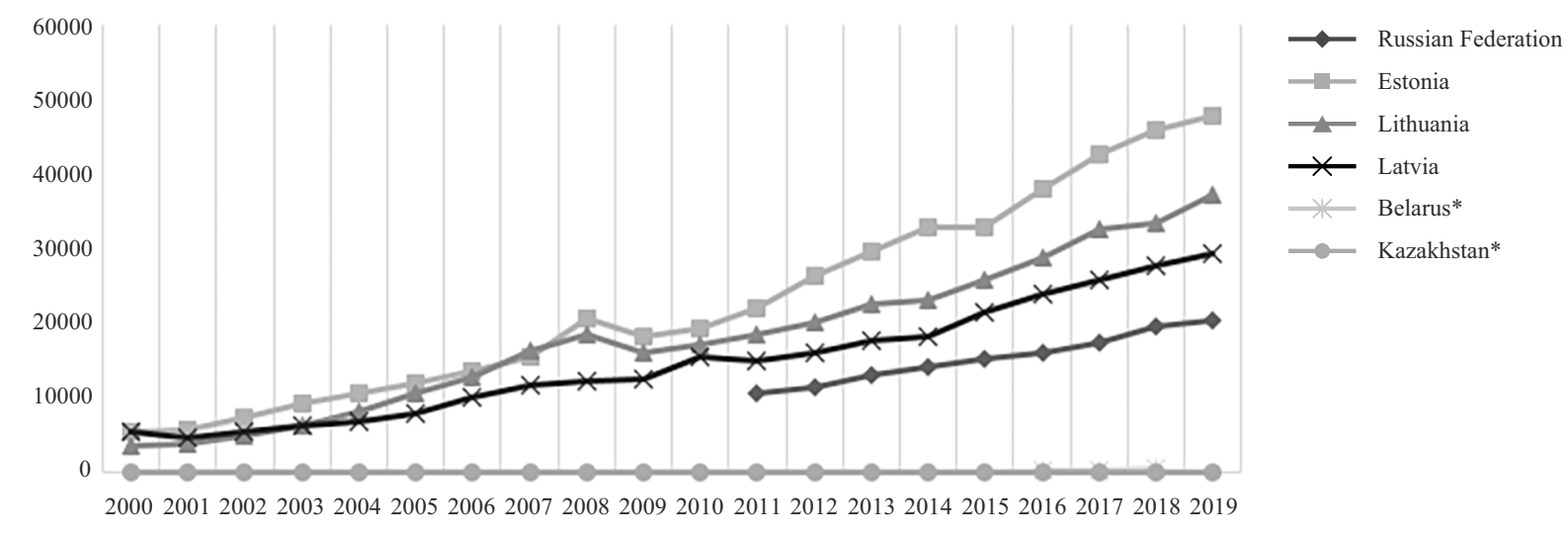

Note: * - no data for Kazakhstan, no comparable data for Belarus due to currency denomination.

Figure 1. Household financial assets, USD per capita (source: compiled by the authors)

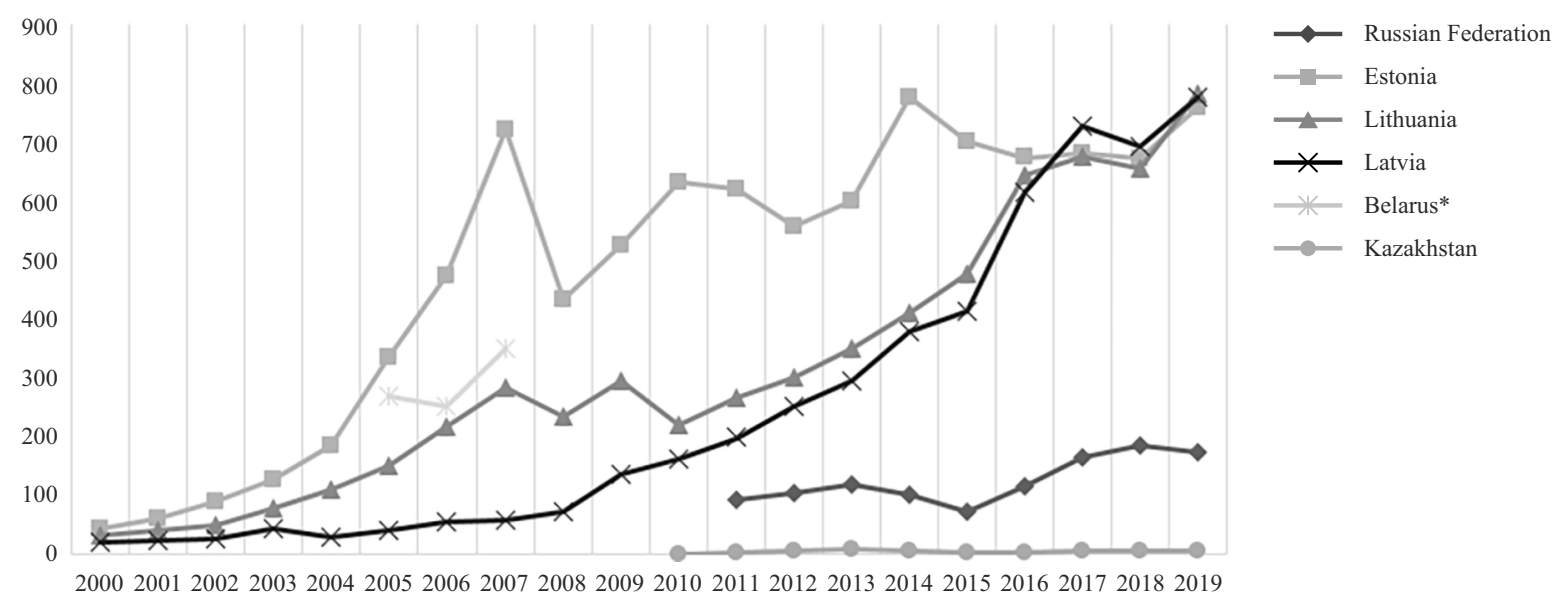

Note: $*$ - no comparable data for Belarus.

Figure 2. Household assets in life insurance reserves, USD (source: compiled by authors)

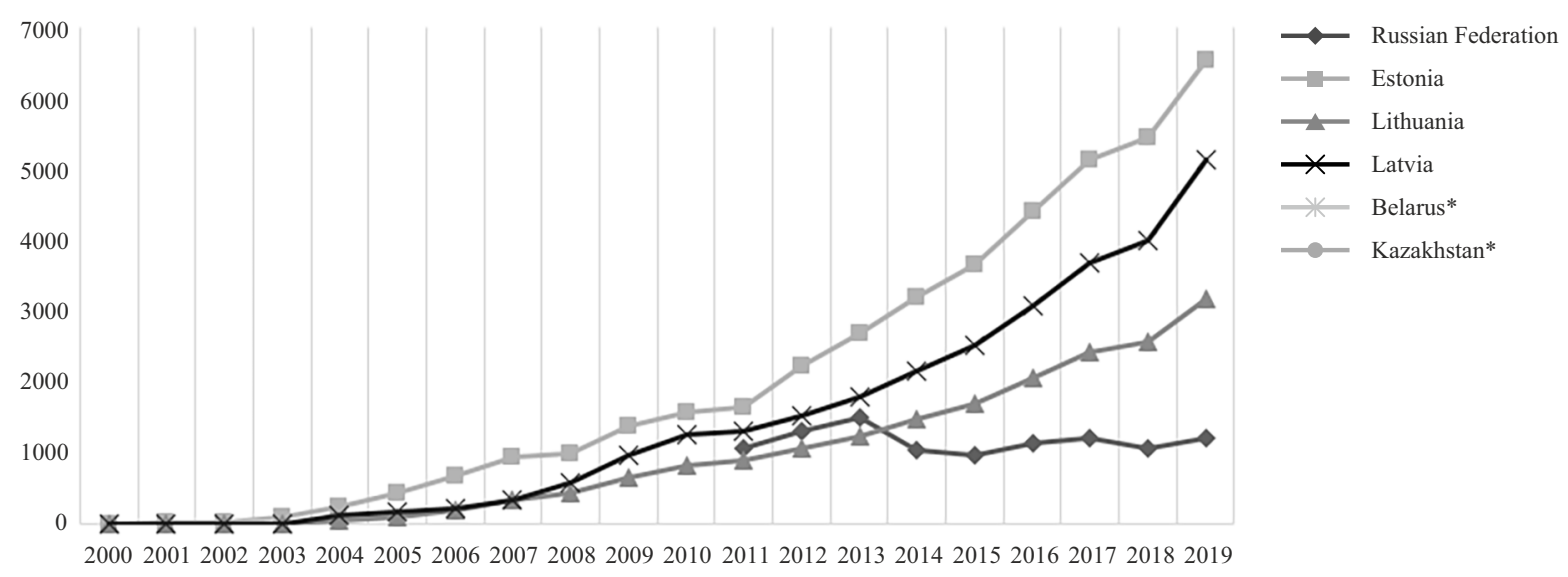

Note: * - no comparable data for Belarus and Kazakhstan.

Figure 3. Household assets in pension schemes, USD (source: compiled by authors)

The system of collective investment and trust management of assets is one of the infrastructure foundations of the financial markets of the studied countries. It is designed to perform the main functions of financial intermediation for the transformation of savings into investments, improving the efficiency of the allocation of financial resources.

The authors compiled data on household assets in life insurance reserves and assets placed in voluntary pension schemes. A summary correlation matrix has been compiled that demonstrates the statistical relationship between total household assets $(Y)$ and the parameters: financial assets per capita $(X 1)$, household life insurance assets $(X 2)$, and household assets in pension schemes $(X 3)$. 
As can be seen from Table 1, in five of the six countries, there is a strong relationship between the variables. The financial condition of households also affects the choice of investment funds. In many developing countries, such as Kazakhstan, the majority of investments are made in conservative bank deposits, while in more developed countries their share is much smaller: investments mainly go to securities, insurance and pension programs.

According to the models of Estonia, Latvia, Lithuania, there is a strong relationship between total household assets and financial assets and assets in pension schemes, while the relationship between total household assets and assets in life insurance reserves is much smaller, which proves the multiple correlation coefficient, the coefficient of determination, the value of which is close to 1 (Table 2).

The statistical significance of the regression equations was checked using the coefficient of determination, the Student's test, and the Fisher test, and the remainder was checked for autocorrelation using the Darbin-Watson test (Table 3).

Since the Fisher coefficient exceeds the table value, it can be concluded that the constructed regression equations are statistically reliable.

Table 1. Summary of the correlation matrix in the FSU countries (source: compiled by authors)

\begin{tabular}{|c|c|c|c|c|c|}
\hline \multirow{5}{*}{ Russian Federation } & & $Y$ & $X 1$ & $X 2$ & $X 3$ \\
\hline & $Y$ & 1 & & & \\
\hline & $X 1$ & 0.989827509 & 1 & & \\
\hline & $X 2$ & 0.792418147 & 0.8067 & 1 & \\
\hline & $X 3$ & -0.26369288 & -0.1873 & 0.165125 & 1 \\
\hline \multirow{5}{*}{ Estonia } & & $Y$ & $X 1$ & $X 2$ & $X 3$ \\
\hline & $Y$ & 1 & & & \\
\hline & $X 1$ & 0.96878 & 1 & & \\
\hline & $X 2$ & 0.663636 & 0.81225 & 1 & \\
\hline & $X 3$ & 0.977977 & 0.985793 & 0.76002 & 1 \\
\hline \multirow{5}{*}{ Lithuania } & & $Y$ & $X 1$ & $X 2$ & $X 3$ \\
\hline & $Y$ & 1 & & & \\
\hline & $X 1$ & 0.988475 & 1 & & \\
\hline & $\mathrm{X} 2$ & 0.986462 & 0.978246 & 1 & \\
\hline & $X 3$ & 0.980466 & 0.963423 & 0.974328 & 1 \\
\hline \multirow{5}{*}{ Latvia } & & $Y$ & $X 1$ & $X 2$ & $X 3$ \\
\hline & $Y$ & 1 & & & \\
\hline & $X 1$ & 0.939950289 & 1 & & \\
\hline & $X 2$ & 0.987290024 & 0.962301 & 1 & \\
\hline & $X 3$ & 0.975367103 & 0.974865 & 0.985924 & 1 \\
\hline \multirow{5}{*}{ Belarus } & & $Y$ & $X 1$ & $X 2$ & $X 3$ \\
\hline & $Y$ & 1 & & & \\
\hline & $X 1$ & 0.999891969 & 1 & & \\
\hline & $X 2$ & 0.781511067 & 0.787576 & 1 & \\
\hline & $X 3$ & 0.992603844 & 0.993053 & 0.808207 & 1 \\
\hline \multirow{5}{*}{ Kazakhstan } & & $Y$ & $X 1$ & $X 2$ & $X 3$ \\
\hline & $Y$ & 1 & & & \\
\hline & $X 1$ & - & - & & \\
\hline & $X 2$ & 0.508445 & - & 1 & \\
\hline & $X 3$ & 0.716307 & - & 0.22901 & 1 \\
\hline
\end{tabular}

Table 2. Relationship between household assets and investments in insurance and pension schemes (source: compiled by authors)

\begin{tabular}{|c|l|c|c|c|l|}
\hline No. & Country & Normalized R-square, (\%) & DW criterion & The number of observations & Depends \\
\hline 1. & $\begin{array}{l}\text { Russian } \\
\text { Federation }\end{array}$ & 98 & 1.54 & 9 & Fairly strong dependency \\
\hline 2. & Estonia & 98 & 0.96 & 20 & Fairly strong dependency \\
\hline 3. & Lithuania & 99 & 1.16 & 20 & Fairly strong dependency \\
\hline 4. & Latvia & 97 & 2.41 & 20 & Fairly strong dependency \\
\hline 5. & Belarus & 99 & 1.34 & 14 & Fairly strong dependency \\
\hline 6. & Kazakhstan & 53 & 1.87 & 10 & There is a dependency \\
\hline
\end{tabular}


A. A. Brylev, A. N. Mitrofanova, V. A. Khoteeva. 2021. Changing role of pension funds and insurance companies as sources of household well-being in the long term: the example of the countries of the former Soviet Union

Table 3. Checking the statistical significance of multiple regression equations (source: compiled by authors)

\begin{tabular}{|c|c|c|c|c|}
\hline \multirow{2}{*}{\begin{tabular}{|l} 
Country \\
Estonia
\end{tabular}} & \multicolumn{2}{|c|}{$\begin{array}{l}\text { Checking the significance of the parameters of } \\
\text { the multiple regression equation ( } t \text {-statistics) }\end{array}$} & \multicolumn{2}{|c|}{$\begin{array}{c}\text { Checking the overall quality of the multiple regression } \\
\text { equation ( } F \text {-statistics) }\end{array}$} \\
\hline & $\begin{array}{l}T_{t a b l}=2.473 \\
t_{0}=1.314<T_{t a b l} \\
t_{1}=4.099>T_{t a b l} \\
t_{2}=5.759>T_{t a b l} \\
t_{3}=1.824<T_{t a b l}\end{array}$ & $\begin{array}{l}\text { The statistical significance of } \\
\text { the regression coefficients } b_{0} \\
\text { and } b_{3} \text { is not confirmed } \\
\text { The statistical significance of } \\
\text { the regression coefficients } b_{1} \\
\text { and } b_{2} \text { is confirmed }\end{array}$ & $\begin{array}{l}F=377.73 \\
\text { Table value for degrees of freedom } \\
k 1=3 \\
\text { and } \\
k 2=n-m-1=20-3-1=16 \\
F k p(3 ; 16)=3.24\end{array}$ & $\begin{array}{l}\text { Since the actual value of } \\
F>F k p \text {, the coefficient } \\
\text { of determination is } \\
\text { statistically significant } \\
\text { and the regression } \\
\text { equation is statistically } \\
\text { reliable }\end{array}$ \\
\hline Lithuania & $\begin{array}{l}T_{\text {tabl }}=2.473 \\
t_{0}=3.749>T_{t a b l} \\
t_{1}=3.828>T_{\text {tabl }} \\
t_{2}=1.632<T_{\text {tabl }} \\
t_{3}=2.475>T_{\text {tabl }}\end{array}$ & $\begin{array}{l}\text { The statistical significance of } \\
\text { the regression coefficient } b_{2} \\
\text { is not confirmed } \\
\text { The statistical significance } \\
\text { of the regression coefficients } \\
b_{0}, b_{1} \text {, and } b_{3} \text { is confirmed }\end{array}$ & $\begin{array}{l}F=518.11 \\
\text { Table value for degrees of freedom } \\
k 1=3 \\
\text { and } \\
k 2=n-m-1=20-3-1=16 \\
F k p(3 ; 16)=3.24\end{array}$ & $\begin{array}{l}\text { Since the actual value of } \\
F>F k p \text {, the coefficient } \\
\text { of determination is } \\
\text { statistically significant } \\
\text { and the regression } \\
\text { equation is statistically } \\
\text { reliable }\end{array}$ \\
\hline atv & $\begin{array}{l}T_{t a b l}=2.473 \\
t_{0}=4.171>T_{t a b l} \\
t_{1}=1.441<T_{t a b l} \\
t_{2}=4.159>T_{t a b l} \\
t_{3}=1.087<T_{t a b l}\end{array}$ & $\begin{array}{l}\text { The statistical significance of } \\
\text { the regression coefficients } b_{1} \\
\text { and } b_{3} \text { is not confirmed } \\
\text { The statistical significance of } \\
\text { the regression coefficients } b_{0} \\
\text { and } b_{2} \text { is confirmed }\end{array}$ & $\begin{array}{l}F=234.55 \\
\text { Table value for degrees of freedom } \\
k 1=3 \\
\text { and } \\
k 2=n-m-1=20-3-1=16 \\
F k p(3 ; 16)=3.24\end{array}$ & $\begin{array}{l}\text { Since the actual value of } \\
F>F k p \text {, the coefficient } \\
\text { of determination is } \\
\text { statistically significant } \\
\text { and the regression } \\
\text { equation is statistically } \\
\text { reliable }\end{array}$ \\
\hline $\begin{array}{l}\text { Russian } \\
\text { Federation }\end{array}$ & $\begin{array}{l}T_{\text {tabl }}=3.163 \\
t_{0}=1.211<T_{\text {tabl }} \\
t_{1}=9>T_{\text {tabl }} \\
t_{2}=0.796<T_{\text {tabl }} \\
t_{3}=1.78<T_{\text {tabl }}\end{array}$ & $\begin{array}{l}\text { The statistical significance of } \\
\text { the regression coefficients } b_{0} \text {, } \\
b_{2} \text {, and } b_{3} \text { is not confirmed } \\
\text { The statistical significance of } \\
\text { the } b_{1} \text { regression coefficients } \\
\text { is confirmed }\end{array}$ & $\begin{array}{l}F=133.534 \\
\text { Table value for degrees of freedom } \\
k 1=3 \\
\text { and } \\
k 2=n-m-1=9-3-1=5, \\
F k p(3 ; 5)=5.41\end{array}$ & $\begin{array}{l}\text { Since the actual value of } \\
F>F k p \text {, the coefficient } \\
\text { of determination is } \\
\text { statistically significant } \\
\text { and the regression } \\
\text { equation is statistically } \\
\text { reliable }\end{array}$ \\
\hline DCla & $\begin{array}{l}T_{\text {tabl }}=2.634 \\
t_{0}=1.582<T_{\text {tabl }} \\
t=33.187>T_{\text {tabl }} \\
t_{2}=2.663>T_{\text {tabl }} \\
t_{3}=0.181<T_{\text {tabl }}\end{array}$ & $\begin{array}{l}\text { The statistical significance of } \\
\text { the regression coefficients } b_{0} \\
\text { and } b_{3} \text { is not confirmed } \\
\text { The statistical significance of } \\
\text { the regression coefficients } b_{1} \\
\text { and } b_{2} \text { is confirmed }\end{array}$ & $\begin{array}{l}F=27438 \\
\text { Table value for degrees of freedom } \\
k 1=3 \\
\text { and } \\
k 2=n-m-1=14-3-1=10 \\
F k p(3 ; 10)=3.71\end{array}$ & $\begin{array}{l}\text { Since the actual value of } \\
F>F k p, \text { the coefficient } \\
\text { of determination is } \\
\text { statistically significant } \\
\text { and the regression } \\
\text { equation is statistically } \\
\text { reliable }\end{array}$ \\
\hline Kazakhstan & $\begin{array}{l}T_{t a b l}=2.841 \\
t_{0}=5.594>T_{t a b l} \\
t_{1}=1.553<T_{t a b l} \\
t_{2}=2.663<T_{t a b l}\end{array}$ & $\begin{array}{l}\text { The statistical significance of } \\
\text { the regression coefficients } b_{1} \\
\text { and } b_{2} \text { is not confirmed } \\
\text { The statistical significance of } \\
\text { the regression coefficients } b_{0} \\
\text { is confirmed }\end{array}$ & $\begin{array}{l}F=6.014 \\
\text { Table value for degrees of freedom } \\
k 1=2 \\
\text { and } \\
k 2=n-m-1=10-2-1=7, \\
F k p(2 ; 7)=4.74\end{array}$ & $\begin{array}{l}\text { Since the actual value of } \\
F>F k p \text {, the coefficient } \\
\text { of determination is } \\
\text { statistically significant } \\
\text { and the regression } \\
\text { equation is statistically } \\
\text { reliable }\end{array}$ \\
\hline
\end{tabular}

In the model of Belarus, having calculated the Darbin-Watson criterion, the authors came to the conclusion that there is a significant autocorrelation, since the values of the calculated parameter significantly exceed the tabular interval values. Based on this we can say that the presence of autocorrelation of the random errors of the regression model led to deterioration in the quality of the OLS-estimates of the regression parameters, and to drive the test statistics, which was tested as a model, that has created the artificial improvement of the quality of the model relative to the actual level of precision. We observe this on the basis of regression statistics. A possible reason for the ongoing processes can be considered, the denomination of the Belarusian ruble in Belarus in 2016, the currency was denominated 10000 times.

In the model of the Russian Federation, the constructed correlation matrix shows that the greatest relationship is observed between total assets and financial assets. Financial assets, in turn, are closely correlated with assets in life insurance reserves. In this case, an interesting situation is formed: a weak inverse relationship between $Y$ and $X 3$. The multiple correlation coefficient shows that the relationship between trait $Y$ and factors $X i$ is strong, and the determination coefficient proves the same. Since the Fisher coefficient exceeds the table value, we can conclude that the equation is statistically reliable. 


\section{Conclusions}

As a result of the analysis of the primary data, the positive dynamics of household assets, as well as the growth of investments in pension and insurance schemes (Figure 2 and 3), which is typical for countries with a higher standard of living, were revealed.

The presented correlation and regression models of the countries of the former Soviet Union demonstrate a high dependence between household assets and their participation in pension and insurance schemes, which confirms the hypothesis put forward.

From the presented models of the FSU countries, which demonstrate the changing role of pension funds and insurance companies as sources of household welfare formation in the long term, the role of non-state pension funds and insurance companies in the financial markets is revealed.

However, there are a number of problems specific to the countries under study. First of all, the lack of free funds among the population, low income and the inability to save something else for retirement. However, the weak development of the non-state pension provision (NGO) segment is much more influenced by other factors. To convince a person to open such a program, you need professional financial consultants, as well as serious incentives, primarily tax incentives, and modern product solutions.

And, finally, another reason for the lack of growth in demand in the segment of non-state pension insurance is the too strict framework of pension programs. The legislation imposes strict restrictions in terms of terms and payment options for both mandatory pension insurance programs and NGO programs, which, given the voluntary nature of the latter, seems illogical. Also, for NGO programs, you need to think about the widest possible variety of annuity payments - monthly, lifetime, with a guaranteed period, spousal pension options, etc. This practice already exists in many countries.

In addition, pension funds need to move away from the single-product business model. In fact, the NPF currently has only two products in its arsenal - individual and corporate programs. Unlike other financial institutions, pension funds in the FSU countries are restricted by law and cannot expand their product line with related services and services, such as insurance, medicine, etc., which makes them less attractive in comparison with other financial services.

On the other hand, it is necessary to encourage citizens and business entities to conclude an insurance contract as one of the tools to protect their property interests, as well as to raise awareness about the insurance services provided, for which it is necessary to legislate the obligation of insurers to inform the consumer of insurance services about the terms of insurance, insurance rates, to explain to the policyholder the terms of the insurance contract, to disclose information about their activities. This measure will not only be aimed at popularizing insurance, but will also allow you to evaluate the offered insurance products.

The main reason for the low demand for insurance is the insufficient level of income and financial literacy of the population. It is proposed to solve these problems in the following way: to develop special insurance services aimed at consumers with low incomes and providing for the use of general principles for the provision of such insurance services, a simplified procedure for concluding contracts, including the settlement of losses.

Ensuring the possibility of remote implementation of insurance products through information and telecommunications networks and the conclusion of an insurance contract in electronic form should also contribute to improving the availability of insurance services.

Pension funds, along with insurance companies and other participants in the collective investment market, are the most active representatives of institutional investors in the economy. Pension and insurance savings are long-term investment resources that can significantly accelerate economic growth in the country and, as a result, investing these funds allows you to protect them from depreciation as a result of inflation and receive income from their placement, significantly exceeding the amount of non-paid insurance premiums. Therefore, NPFs are not only a potential source of financial resources in the securities market, but also provide an opportunity to take care of their well-being in old age, that is, to influence the size of the future pension. Improving the well-being of the population creates additional demand, which means that it pushes the growth of the country's economy.

In the future, the authors plan to determine whether there is a relationship between the volume of investments in pension and insurance schemes, what determines the structure of obligations of insurance companies and pension funds and how it has changed over the past 20 years. It is also of particular interest to consider the impact of the current crisis on changes in the asset structure of insurance companies and pension funds.

\section{Funding}

This study was prepared as part of the activities of the Financial Clinic (Financial Literacy Center) St. Petersburg State University. Under the guidance of Zhanna V. Pisarenko.

Funding is supported by RFBR Grant [number 19-510-92001]. 
A. A. Brylev, A. N. Mitrofanova, V. A. Khoteeva. 2021. Changing role of pension funds and insurance companies as sources of household well-being in the long term: the example of the countries of the former Soviet Union

\section{References}

Belozyorov, S. A., \& Pisarenko, Zh. V. (2015). Pension reforms in countries with developed and transitional economies. Economy of Region, 4, 158-169. https://doi.org/10.17059/2015-4-13

Bernard, J.-B., \& Berthet, L. (2016). French households fnancial wealth: A macro and micro overview of changes in the last 20 years? Revue d'Economie Politique, 126(5), 721-787. https://doi.org/10.3917/redp.265.0721

Boldyreva, N. B., \& Reshetnikova, L. G. (2020). Effectiveness of investment activities of managers in the mandatory pension insurance system. Vestnik Sankt-Peterburgskogo Universiteta. Ekonomika [St Petersburg University Journal of Economic Studies], 36(3), 483-513. https://doi.org/10.21638/spbu05.2020.306

Bover, O., Schürz, M., Slacalek, J., \& Teppa, F. (2016). Eurosystem household finance and consumption survey: Main results on assets, debt, and saving. International Journal of Central Banking, 12(2), 1-13.

Brown, S., Ghosh, P., Su, L., \& Taylor, K. (2015). Modelling household finances: A Bayesian approach to a multivariate two-part model. Journal of Empirical Finance, 33, 190-207. https://doi.org/10.1016/j.jempfin.2015.03.017

Chernova, G. V., Kalaida, S. A., \& Pisarenko, Zh. V. (2010). Methodological aspects of anti-crisis management. Vestnik of Saint-Petersburg University, 2, 89-99. https://elibrary.ru/item.asp?id=15247566

Gomes, F., Haliassos, M., \& Ramadorai, T. (2020). Household finance. Journal of Economic Literature, 142(2), 1-142. https://www.researchgate.net/publication/339974769

International Labour Organization. (2017, November 29). World Social Protection Report 2017-19: Universal social protection to achieve the Sustainable Development Goals. https://www.ilo.org/global/publications/books/WCMS_604882/lang--en/index.htm

Jang, I. (2019). The distributive impact of private pensions in the context of the institutional designs of public pension systems across OECD countries. International Journal of Social Welfare, 28(2), 152-166. https://doi.org/10.1111/ijsw.12365

Kukk, M. (2017). How does household debt affect financial asset holdings? evidence from euro area countries. Studies in Economics and Finance, 34(2), 194-212. https://doi.org/10.1108/SEF-02-2016-0031

Kunovac, M. (2020). Distribution of household assets in Croatia. Public Sector Economics, 44(3), 265-297. https://doi.org/10.3326/pse.44.3.1

Kuznetsova, N. P., \& Pisarenko, Zh. V. (2016). The role of the funded component in pension reforms in Europe and Russia. Problems of the Modern Economy, 1(57), 149-156. http:/www.m-economy.ru/art_e.php?nArtId=5709

Levine, L. (2013). The distribution of household wealth. In Income and wealth distribution: Perspectives and considerations (pp. 97-110). www.scopus.com

Liu, Y., Pu, L., \& Cao, C. (2014). The research on household financial multi-objective decision based on assets and liabilities management. In Proceedings of the 5th International Asia Conference on Industrial Engineering and Management Innovation (pp. 429-433). Atlantis Press. https://doi.org/10.2991/iemi-14.2014.79

Manou, K., Palaios, P., \& Papapetrou, E. (2020). Housing wealth, household debt, and financial assets: Are there implications for consumption? Empirical Economics. https://doi.org/10.1007/s00181-020-01911-6

Morozko, N., \& Didenko, V. (2018). Determinants of the savings market in Russia. Banks and Bank Systems, 13(1), 196-208. https://doi.org/10.21511/bbs.13(1).2018.18

Obben, J., \& Waayer, M. (2011). New Zealand's old-age pension scheme and household saving. International Journal of Social Economics, 38(9), 767-788. https://doi.org/10.1108/03068291111157230

Organisation for Economic Co-operation and Development. (2019, November 27). Pensions at a Glance 2019: OECD and G20 indicators. https://www.oecd.org/els/oecd-pensions-at-a-glance-19991363.htm

Pastoráková, E., Brokešová, Z., \& Péliová, J. (2017). Proactive approach to private pension savings: Key determinants [Proaktívny prístup k tvorbe súkromných dôchodkových úspor: kl'účové determinanty]. Politická ekonomie, 65(6), 709-727. https://doi.org/10.18267/j.polek.1171

Pisarenko, Zh. V., \& Kuznetsova, N. P. (2019). Institutional investors in the context of sustainable development. In 6th International Scientific and Practical Conference “Sustainable Development: Society and Economy” (pp. 350-352). https://elibrary.ru/item.asp?id=44291231

Rosa, E. S. T. (2016). Households in the minskyan approach: Issues and consequences of the indebtness of American households in the XX and early XXI century [As famílias na abordagem minskyana: Aspectos e desdobramentos do endividamento das famílias Americanas no século XX e início do XXI]. Revista de Economia Politica, 36(1), 130-149. https://doi.org/10.1590/0101-31572016v36n01a08

Sim, S.-G., \& Lee, S. (2020). The cyclical behavior of household and corporate credit in emerging economies. Emerging Markets Review, 45, 100724. https://doi.org/10.1016/j.ememar.2020.100724

The World Bank. (n.d.). https://www.worldbank.org/en/home

Tomaszewicz, Ł. (2014). Empirical comparative analysis of household sector liabilities and assets in the context of financial crisis. Economics and Sociology, 7(2), 47-63. https://doi.org/10.14254/2071-789X.2014/7-2/5

Unnikrishnan, V., \& Imai, K. S. (2020). Does the old-age pension scheme improve household welfare? Evidence from India. World Development, 134, 105017. https://doi.org/10.1016/j.worlddev.2020.105017

van Santen, P. (2019). Uncertain pension income and household saving. Review of Income and Wealth, 65(4), 908-929. https://doi.org/10.1111/roiw.12383 